\title{
Research Article \\ Effect of sowing dates on different rapeseed varieties under rain fed condition
}

\author{
Gaurav Ranabhat ${ }^{1 *}$, Pramod Tiwari ${ }^{2}$, Ashmita Dhakal $^{1},{\text { Pramod } \text { Oli }^{2}, \text { Amira Chapagain }^{2} \text { and }}$ \\ Susmita Neupane ${ }^{2}$ \\ ${ }^{1}$ Agriculture and Forestry University, Rampur, Chitwan, Nepal \\ ${ }^{2}$ Mid-West Academy and Research Institute, Campus of Live Sciences, Phulbari, Dang, Nepal \\ *Correspondence: ranabhatgaurav07@gmail.com \\ *ORCID: https://orcid.org/0000-0002-3084-7451 \\ Received: September 05, 2020; Accepted: November 22, 2020; Published: January 01, 2021
}

(C) Copyright: Ranabhat et al. (2021).

\begin{abstract}
Rapeseed is a leading oilseed crop of Nepal occupying $85 \%$ of total oilseed cultivation area. This research was conducted to determine the response of different sowing dates on different rapeseed varieties in their final yield under the rain fed condition in Phulbari, Dang. Two rapeseed varieties Unnati and Surkhet Local on three dates of sowing Oct 4, Oct 24 and Nov 14 were tested under two factorial RCBD design in the year 2018 A.D. Data consisted growth attributes like plant height, branch per plant, no. of siliqua per plant, aborted siliqua and siliqua abortion percentage and yield attributes such as biological yield, biomass yield, seed yield, harvest index and test weight. Statistically no difference was found between varieties whereas differences were found on different sowing dates. Result showed that among the varieties, the highest yield $(8.59 \mathrm{q} / \mathrm{ha})$ was obtained in Surkhet Local than in Unnati (8.54 q/ha). In case of sowing dates, higher seed yield was obtained in Oct 4 sown crop (15.93 q/ha) followed by Oct 24 (7.47 q/ha) and Nov 14 (2.29 q/ha). The higher seed yield obtained in early sowing is due to shorter vegetative and longer reproductive phase. The comparison of mean values of the seed yield for interaction between variety and sowing date showed that variety Surkhet Local sown in Oct 4 plant had the highest seed yield $(16.33 \mathrm{q} / \mathrm{ha})$ followed by variety Unnati on same sowing date $(15.54 \mathrm{q} / \mathrm{ha})$. Based on the result obtained, Surkhet Local*Oct 4 performed better in Dang condition.
\end{abstract}

Keywords: Brassica campestris var. toria; Variety; Sowing date; Rain fed

Correct citation:Ranabhat, G., Tiwari, P., Dhakal, A., Oli, P., Chapagain, A., \& Neupane, S. (2021). Effect of sowing dates on different rapeseed varieties under rain fed condition. Journal of Agriculture and Natural Resources, 4(1), 176-190.

DOI: https://doi.org/10.3126/janr.v4i1.33253

\section{INTRODUCTION}

Rapeseed or oilseed rape is one member of the Brassicaceae family. This is a family of plants which has provided mankind with a significant and highly important range of crops, including cabbage and cauliflower (Brassica oleracea) and varieties of mustard (Brassica - various species). The family also includes turnip, the Latin name of which is Brassica rapa, and it is from the species name of turnip - 'rapa' - that the very closely related species Brassica napus receives its curious common name of rape, a name which was first employed in the 14th century and was later applied to all those plants from the family which were primarily grown for the extraction of vegetable oils (as opposed to those grown primarily for the consumption of roots 
Journal of Agriculture and Natural Resources (2021) 4(1): 176-190

ISSN: 2661-6270 (Print), ISSN: 2661-6289 (Online)

DOI: https://doi.org/10.3126/janr.v4i1.33253

or leaves). In Nepal, the most cultivated rapeseed is Brassica campestris var.toria which is called as 'tori' in Nepalese language. The origins of rapeseed - B. napus - are uncertain, partly because of the close relationships and propensity for hybridizations between the different species of Brassica, but also because naming distinctions were not entirely clear until comparatively recent times. The wild form of $B$. napus has not been discovered, and it is possible that it is a natural hybrid between Brassica oleracea (cabbage) and B. rapa (turnip). Even in recent decades, selective breeding of new cultivars have involved hybridizations with several other species in addition to B. napus. But whatever the truth of its botanical history, geographically rapeseed would seem to be a plant originally from southern Europe. Globally, Canada is the largest rapeseed producing country. The statistics shows, in the year 2017/18, the production of rapeseed in Canada is 21.5 MMT (FAOSTAT, 2019). Accordingly, the productions of some leading countries in rapeseed with their production are China 14.4 MMT, India 5.85MMT and USA 1.65 MMT (FAOSTAT, 2019). In Europe, the European Union production of rapeseed is $22.13 \mathrm{MMT}$ (FAOSTAT, 2019).

Oilseed is one of the important cash crops of Nepal, which occupied 2,13,706 ha area, with production of $1,76,186 \mathrm{mt}$ and productivity of $0.82 \mathrm{MT} / \mathrm{ha}$ in 2010/2011, where as in $2011 / 2012$, area increased to 2,14,835 ha, with production of 179145 MT and productivity of $0.83 \mathrm{MT} / \mathrm{ha}$ (MoAC, 2012).Rapeseed (Brassica campestrisL. var. toria) alone occupies about $85 \%$ of the total oilseed area in the country and it is a dominant winter season oilseed crop(Basnet,2005). Other oilseed crops grown in the country are soybean, sunflower, sesame, groundnut, castor, linseed, and niger. Nepal's conventional oil crop is rapeseed-mustard which is grown in 1,65,560 ha of land with total production of 98,130 mt. On an average, $38 \%$ oil recovery is obtained although this rate is low due to inefficient oil mills in rural areas and losses during milling (Bhandari, 2015). Recently, the area of oilseed cultivation in Nepal is 207978 ha with the production of $214451 \mathrm{MT}$ and yield is $1031 \mathrm{~kg} / \mathrm{ha}$ (MOADSTAT,2016). Among which, rapeseed is cultivated in the area of 160405 ha with the production and yield of $159710 \mathrm{MT}$ and $996 \mathrm{~kg} / \mathrm{ha}$ respectively (MOADSTAT, 2016). It is mostly grown after monsoon maize in upland and after early rice in lowland of Terai, inner Terai and mid-hills (Ghimire et al., 2000). In Dang district, the rapeseed production area is 17,500 ha, with the production of 18,350 MT and yield 1,049 kg/ha (MOADSTAT,2016). This crop is important from income generation point of view and is prominent sources of fats, protein and vitamins as compared to cereals and legumes in Nepalese diet (Chaudhary et al., 1993). Its seeds contain $40-45 \%$ oil and 20-25\% protein(Hasanuzzaman et al., 2008). Similarly, 4.8\% nitrogen, $2 \%$ phosphorus and $1.3 \%$ potash can be obtained from mustard oil cake(Prasai and Yadhav, 1999). Rapeseed is a cross-pollinated crop. It requires sufficient pollinating agents for better pollination and seed production. The flowers of rapeseed are very attractive to bees. Honeybees visit rapeseed flowers for collection of both pollen and nectar, which in turn results into florets cross-pollination. Honeybees are naturally important pollinators of plants throughout their natural range.

The productivity of rapeseed in Nepal is considerably lower as compared to the world productivity. There are several factors responsible for the low productivity of rapeseed (Bhatta et al., 2019). Fink et al., (2006) stated that sowing date is one of the most important production decisions. Either early planting or late planting can result in lower yield because the probability exists that unfavorable climatic conditions can occur after planting or during the growing season.Therefore, determination of sowing dates for maize genotypes is very crucial for better crop yield (BK et al., 2015).Crop cultivars show distinctive variation in response pattern among 
them related to planting date (Shrestha et al., 2018). Timely sowing of rapeseed has proven a key to maximize yield potential and by default reduce risk. With the delay in sowing date, all the investigated traits declined (Baghdadi et al.,2012).Too early or too late sowing of rapeseed has been found to be unfavorable (Hocking and Stapper, 2001;Robertson et al.,2004; Uzun et $a l$. 2009).The early sowing produced higher seed yield this may be due to the variation in temperature, or attributed to more light, water and mineral absorption by plant canopies thus,increasing photosynthetic capacity (Fathi et al.,2003).Determining suitable planting date plays an important role in conformation of plant growth stages with desirable environmental conditions which results in maximum yield. Planting date has a considerable effect on seed yield by influencing the yield components so that late planting decreases secondary branches/plant and pods/plant and finally causes a remarkable reduction in seed yield (Thurling, 1974).

\section{MATERIALS AND METHODS}

\section{Plant materials and site description}

Two different rapeseed varieties, viz. Surkhet Local and Unnati which are preferred by the farmers of this locality were selected. Varieties were searched among the available agro vets and agricultural cooperatives of this area. The experiment was carried out in the field of Campus of Live Sciences under Agronomy Department in Phulbari, Dang. Dang Deukhuri District is located in Inner Terai in Province No. 5 in Mid-western Nepal. The district, with Ghorahi as its headquarters, covers $2,955 \mathrm{~km}^{2}$ and has a population of $5,48,141$. The site lies within the tropical agro ecological belt, between latitude $28.1545^{\circ} \mathrm{N}$ and longitude $82.3235^{\circ}$ E. It is $448.1 \mathrm{~km}$ west from Kathmandu, the capital of the country. This valley lies in between the Mahabharata range in the North and Chure hill in the South.

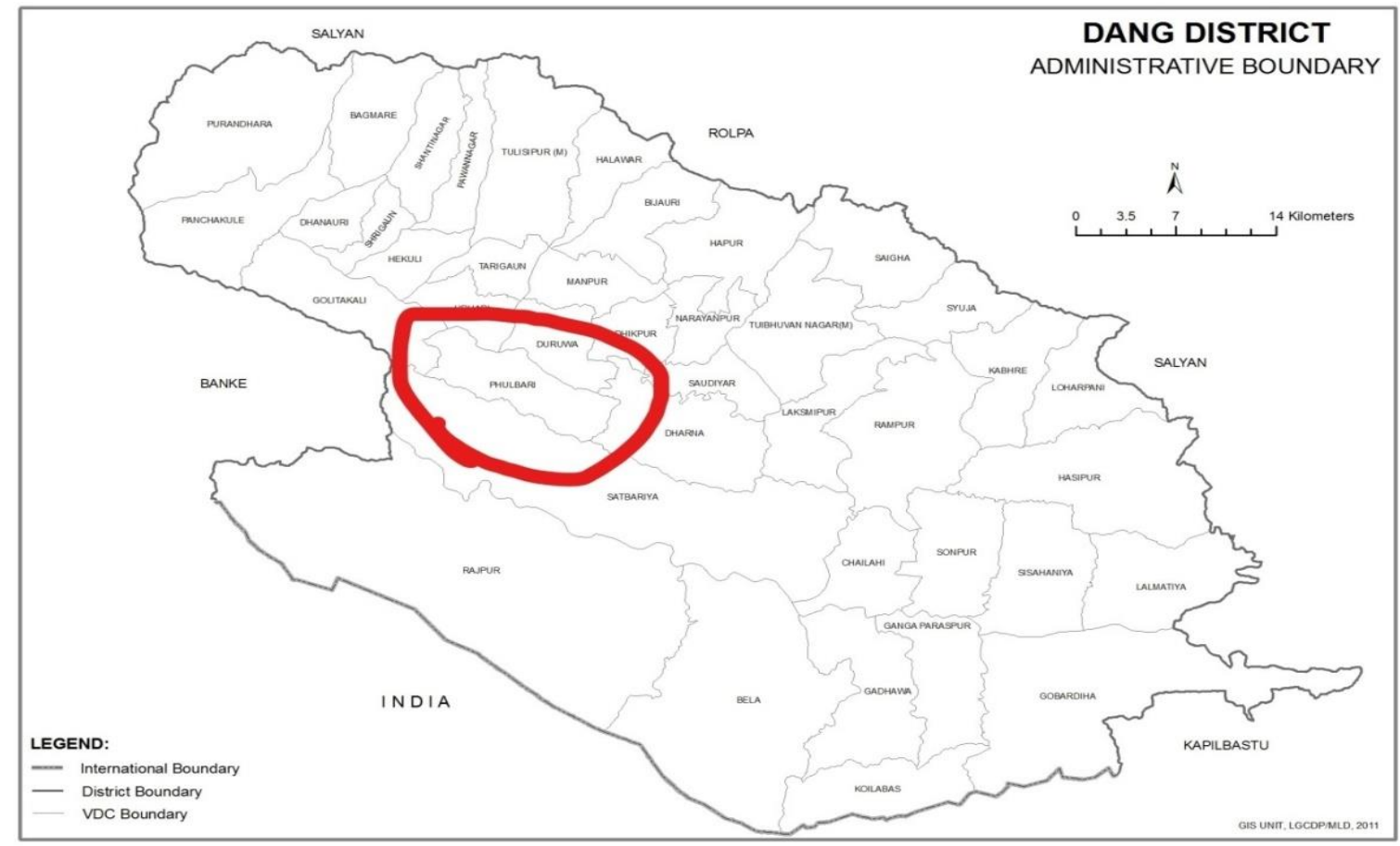

Figure1. Map of Dang district showing Phulbari village (inside red circle). 


\section{Climatic data}

With an elevation ranged from $700 \mathrm{~m}$ to $1500 \mathrm{~m}$, the research site has a humid, subtropical climate, warm in the winter and hot (often over $40^{\circ} \mathrm{C}$ ) in the summer. Average temperatures ranged from $8.08{ }^{\circ} \mathrm{C}\left(46.54{ }^{\circ} \mathrm{F}\right)$ in December-January (coldest months) to $34.91^{\circ} \mathrm{C}\left(94.84{ }^{\circ} \mathrm{F}\right)$ in June. The weather parameters like average, maximum and minimum temperature $\left({ }^{\circ} \mathrm{C}\right)$, rainfall $(\mathrm{mm})$ and relative humidity $(\%)$ were recorded during the crop season of Oct 2018 to Feb 2019 (fig 2). The research site received a total of $133.09 \mathrm{~mm}$ of rainfall during the research period. Precipitation increased gradually from November $(0 \mathrm{~mm})$ to February $(96.9 \mathrm{~mm})$. The minimum temperature was recorded $13^{\circ} \mathrm{C}$ in December whereas maximum temperature was $32^{\circ} \mathrm{C}$ in October. The mean temperature during the research was $20.6^{\circ} \mathrm{C}$. Relative humidity was recorded maximum during February (64\%) and minimum (44\%) during December.

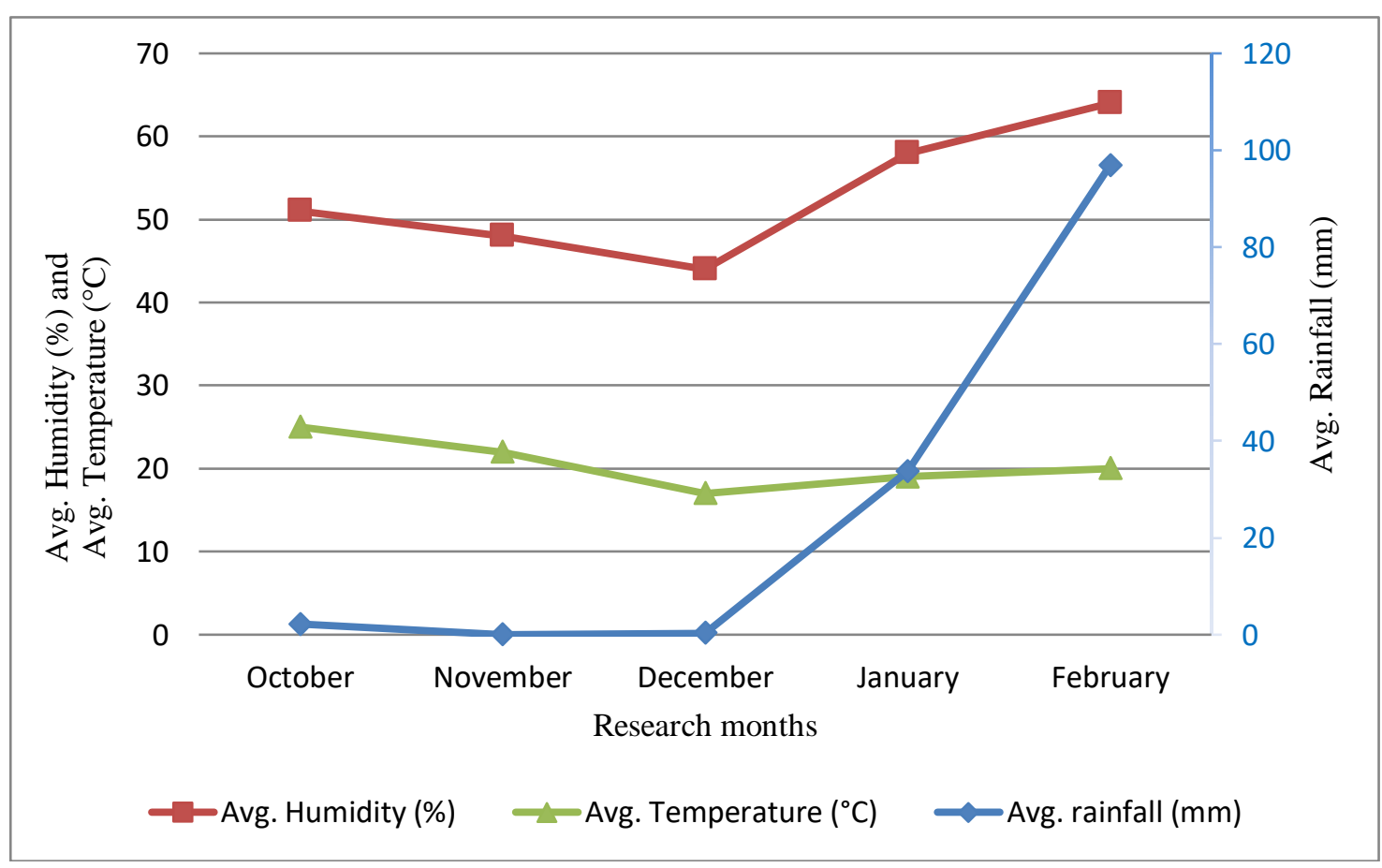

Source: World Weather Online

Figure 2: Meteorological data for the cropping period 2018 to 2019.

\section{Field experiments}

\section{Design of Experiment and treatment details}

The experiment was laid out in two factor RCBD (Randomized Complete Block Design) with six treatments and each treatment was replicated four times, resulting a total of 24 plots. The two factors were varieties (Unnati and Surkhet Local) and sowing dates (Oct 4, Oct 24, and Nov 14). 
Journal of Agriculture and Natural Resources (2021) 4(1): 176-190

ISSN: 2661-6270 (Print), ISSN: 2661-6289 (Online)

DOI: https://doi.org/10.3126/janr.v4i1.33253

Factor A (variety):

$\mathbf{V}_{\mathbf{1}}$ : Unnati $\quad \mathbf{V}_{\mathbf{2}}$ : Surkhet Local

Factor B (sowing dates):

$\begin{array}{lll}\mathbf{D}_{1} \text { : Oct } 4 & \mathbf{D}_{\mathbf{2}} \text { : Oct } 24 & \mathbf{D}_{\mathbf{3}} \text { : Nov } 14\end{array}$

Two different varieties of rapeseed were sown in three dates in the interval of 20 days. The treatment details can be summarized as follows:

$\begin{array}{lll}\mathbf{T}_{\mathbf{1}}=\text { Unnati } * \text { Oct } 4 & \mathbf{T}_{\mathbf{2}}=\text { Unnati } * \text { Oct } 24 & \mathbf{T}_{\mathbf{3}}=\text { Unnati } * \text { Nov } 14 \\ \mathbf{T}_{\mathbf{4}}=\text { Surkhet Local } * \text { Oct } 4 & \mathbf{T}_{\mathbf{5}}=\text { Surkhet Local } * \text { Oct } 24 & \mathbf{T}_{\mathbf{6}}=\text { Surkhet Local } * \text { Nov }\end{array}$
14

\section{Field layout and randomization}

Randomization of the above treatments was done by lottery method. The total number of plots laid out in the entire experiment was 24. Each plot was of $6 \mathrm{~m}^{2}(3 \mathrm{~m} * 2 \mathrm{~m})$. The space between two plots was $0.3 \mathrm{~m}$ and the space between replications was $0.5 \mathrm{~m}$.

\section{Field preparation and sowing}

Land was ploughed with the help of tractor followed by manual harrowing and planking. FYM 10 tons ha ${ }^{-1}$ and 60:40:20 $\mathrm{kg} \mathrm{ha}^{-1}$ NPK was applied. Well decomposed FYM was applied to all the plots and well mixed to the field one week before sowing. The required amount of fertilizer (NPK) as basal dose was applied in each furrow and mixed well. In each plot, the dose of Urea (24.25 $\mathrm{g} \mathrm{plot}^{-1}$ ) was top dressed twice $30 \mathrm{DAS}$ and during flowering stage and the basal dose of MOP (20g plot ${ }^{-1}$ ) and DAP (52.176 $\left.\mathrm{g} \mathrm{plot}^{-1}\right)$ was applied. Line sowing was done in the respective hole made on each furrow after mixing the fertilizers in the recommended geometry of $30 \times 10 \mathrm{~cm}$. Five to six seed was dropped in the depth of $2-3 \mathrm{~cm}$ and covered lightly with the soil manually with the hand. As per the treatment requirement seed was sown on three different dates of Oct 4, Oct 24 and Nov 14.

\section{Data collection and data analysis}

The tabulation of data was done in Microsoft Excel2007. The mean value of data of different parameters were recorded in the study were analyzed by R-STAT version 3.0.3 in the computer software. Data were subjected to Analysis of Variance (ANOVA) to evaluate the significance of the treatment effect. Average means were compared using DMRT (Duncan's Multiple Range Test) at 5\% level of significance. Mean comparison was carried out at $\mathrm{P}<0.01$, and $\mathrm{P}<0.05$ level of significance (Gomez \& Gomez, 1984; Shrestha, 2019).

\section{RESULTS AND DISCUSSION}

\section{Plant height}

Date of sowing was found highly significant with the plant height while varieties and interaction between varieties and date of sowing were not. Among three dates of sowing, Oct 4 with mean $84.715 \mathrm{~cm}$ resulted as the highest plant height followed by Oct 24 with mean $60.325 \mathrm{~cm}$ whereas Nov 14 with mean $46.76 \mathrm{~cm}$ resulted the lowest plant height. Reason for the smaller plant height in the delayed dates of sowing may be due to the shorter time span for crop development and reduced air temperature as similar findings were obtained by Sharma, (1994); Thakur \& Singh, (1998). 
Journal of Agriculture and Natural Resources (2021) 4(1): 176-190

ISSN: 2661-6270 (Print), ISSN: 2661-6289 (Online)

DOI: https://doi.org/10.3126/janr.v4i1.33253

Table 1:Effect of variety and sowing dates on plant height, branch per plant, siliqua per plant, seeds per siliqua, aborted siliqua, siliqua abortion \% of rapeseed varieties during winter season, 2018/19.

Growth Attributes:

\begin{tabular}{|c|c|c|c|c|c|c|}
\hline Treatment & $\begin{array}{l}\text { Plant height } \\
\text { (cm) }\end{array}$ & $\begin{array}{c}\text { No. of } \\
\text { Branch per } \\
\text { plant }\end{array}$ & $\begin{array}{c}\text { No. of } \\
\text { Siliqua per } \\
\text { plant }\end{array}$ & $\begin{array}{c}\text { No. of } \\
\text { aborted } \\
\text { siliqua }\end{array}$ & $\begin{array}{l}\text { Seeds per } \\
\text { siliqua }\end{array}$ & $\begin{array}{c}\text { Siliqua } \\
\text { abortion \% }\end{array}$ \\
\hline \multicolumn{7}{|l|}{ Variety: } \\
\hline Unnati & 65.70 & 6.8 & 93.833 & 4.608 & 14.905 & 6.11 \\
\hline Surkhet Local & 62.166 & 7.541 & 90.141 & 5.341 & 14.425 & 7.645 \\
\hline F-test & NS & $\mathrm{NS}$ & NS & $\mathrm{NS}$ & NS & $\mathrm{NS}$ \\
\hline \multicolumn{7}{|l|}{ Date of sowing: } \\
\hline Oct 4 & $84.715 a$ & 8.025 & $137.43 \mathrm{a}$ & $2.85 b$ & $16.075^{\mathrm{a}}$ & $2.18^{\mathrm{c}}$ \\
\hline Oct 24 & $60.325 b$ & 5.4 & $73.837 b$ & $3.95 b$ & $15.403^{\mathrm{a}}$ & $5.20^{\mathrm{b}}$ \\
\hline Nov 14 & $46.762 c$ & 8.087 & $64.68 \mathrm{~b}$ & $8.12 \mathrm{a}$ & $12.51^{\mathrm{b}}$ & $13.24^{\mathrm{a}}$ \\
\hline F-test & $* *$ & NS & $* *$ & $* *$ & $* *$ & $* *$ \\
\hline Interaction & NS & NS & NS & NS & $\mathrm{NS}$ & NS \\
\hline $\mathrm{CV}(\%)$ & 10.396 & - & 32.709 & 48.94 & 8.35 & 32.22 \\
\hline Grand mean & 63.93 & - & 91.98 & 4.97 & 14.66 & 6.87 \\
\hline LSD & 7.029 & - & 32.222 & 2.697 & 1.186 & 2.306 \\
\hline
\end{tabular}

Note: NS= Non-significant, $*=$ Significant and $* *=$ Highly significant, CV $=$ Coefficient of Variation,LSD= Least Significant Difference.

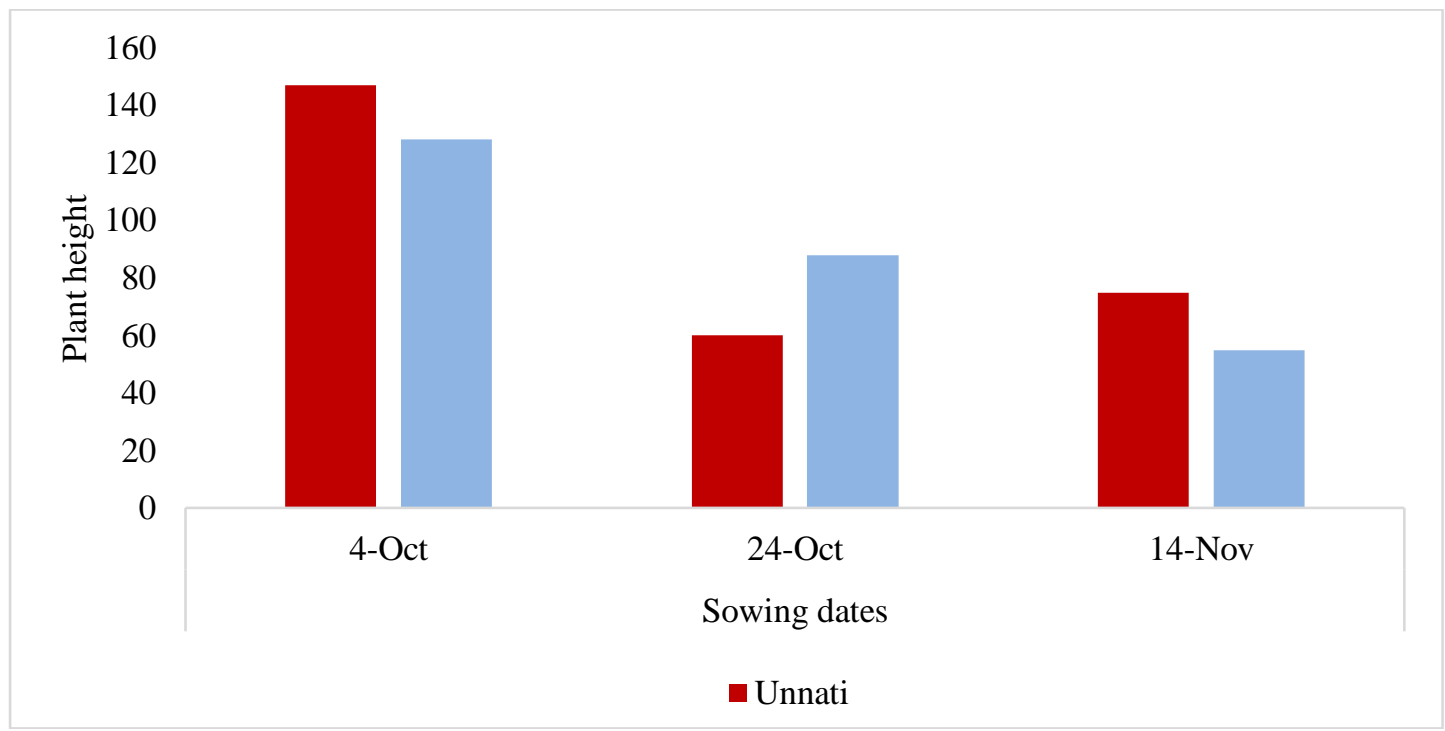

Figure 3. Effect of date of sowing on plant height.

\section{Branch per plant}

Date of sowing, varieties and their interaction did not show any significant result in branch per plant. The grand mean of branch per plant was 7.17. Maximum number of branches was found in Nov 14 (8.087) sown crop followed by Oct 4 (8.025) and lowest was found in Oct 24 (5.4) in case of sowing dates. But in case of variety, maximum branch per plant was found in Surkhet Local (7.541) followed by Unnati (6.8).

\section{Siliqua per plant}

The number of siliqua per plant is the most important component of the seed yield in rapeseed (Angadi et al., 2003). It was significantly affected by different dates of sowing but was affected non-significantly by varieties and interaction of dates of sowing and varieties. Crop sown on 
October 4 recorded significantly higher number of siliqua per plant (137.437), Nov 14 (64.68) recorded the lowest no. of siliqua per plant which is at par with Oct 24 (73.83). Reason for more number of siliqua per plant in the earliest date of sowing (October 4) might be due to longer reproductive phase, suitable temperature and translocation of more photosynthates from source to sink than later dates of sowing.

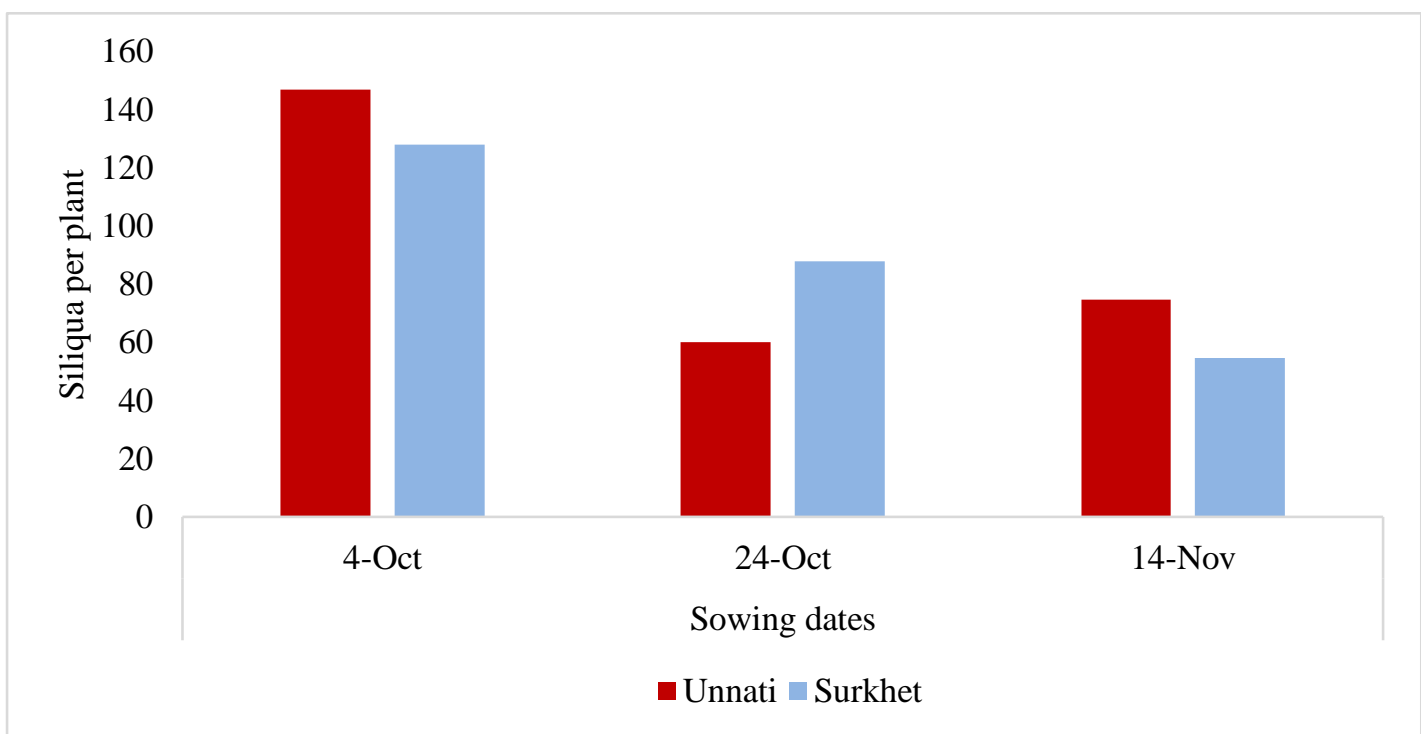

Figure 4. Relationship between siliqua per plant and treatments.

\section{Seeds per siliqua}

Among the three dates of sowing, crop sown on October4 produced the highest number of seeds per siliqua (16.08) followed by October 24 (15.4) and lowest with November 14 sowing (12.52)as reported by Andersson and Benglsson, (1989) and Sudeep et al., (1996). Date of sowing was found highly significant but the differences were non-significant among the varieties and their interactions. Due to translocation of more photosynthates from source to sink, suitable temperature and longer reproductive phase are the major reasons behind the more numbers of siliqua per plant in the earliest sowing than later dates of sowing.

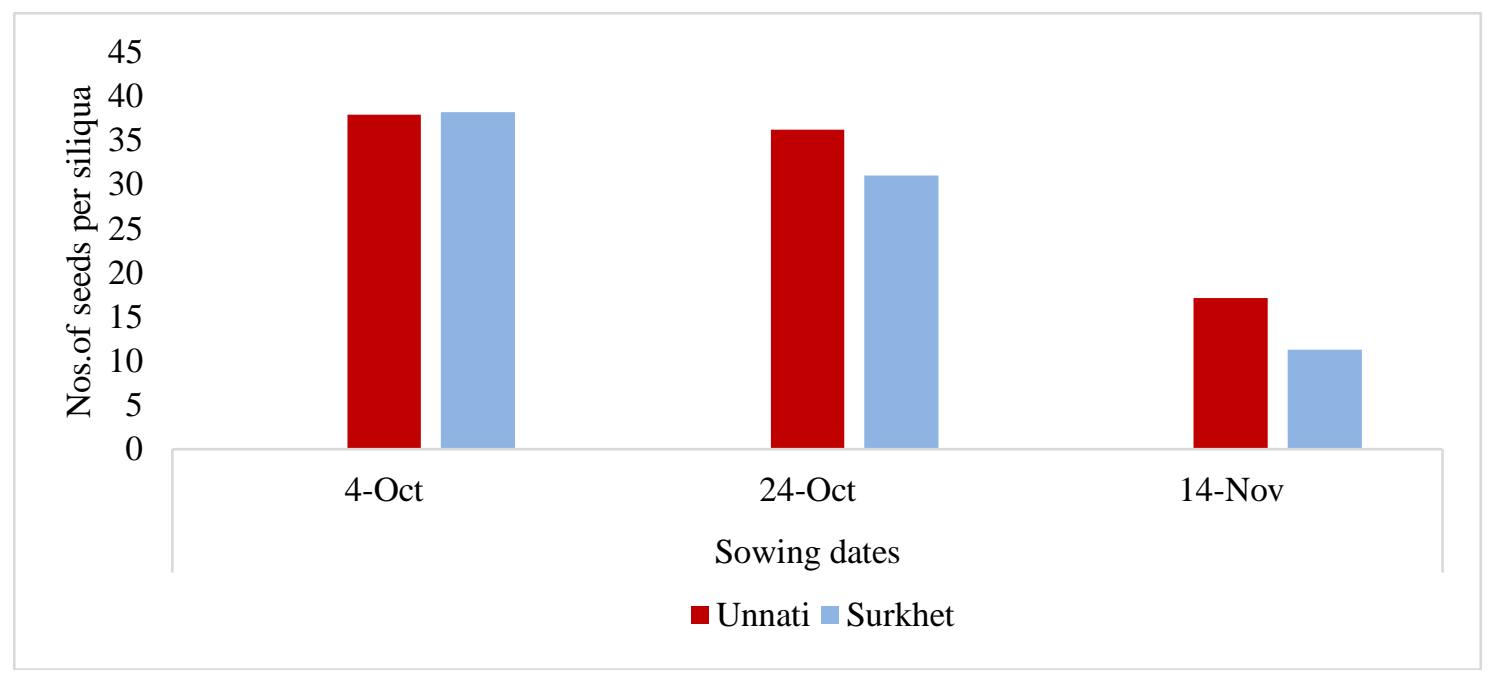

Figure 5. Relationship between varieties and date of sowing on seeds per siliqua 


\section{Aborted siliqua}

Abortion of siliqua was significantly affected by date of sowing but was not affected by variety and their interaction. Among the dates, the higher aborted siliqua was observed in delayed sowing than earlier two dates. The first date of sowing had 2.850 aborted siliqua which is at par with second date of sowing with 3.950 aborted siliqua whereas the delayed date had 8.125, which is also in agreement with the study of Alam et al., (2014). The higher abortion of siliqua in delayed date might be due to severe fall in temperature and depleted soil residual moisture which hampered the fertilization process and nutritional translocation.

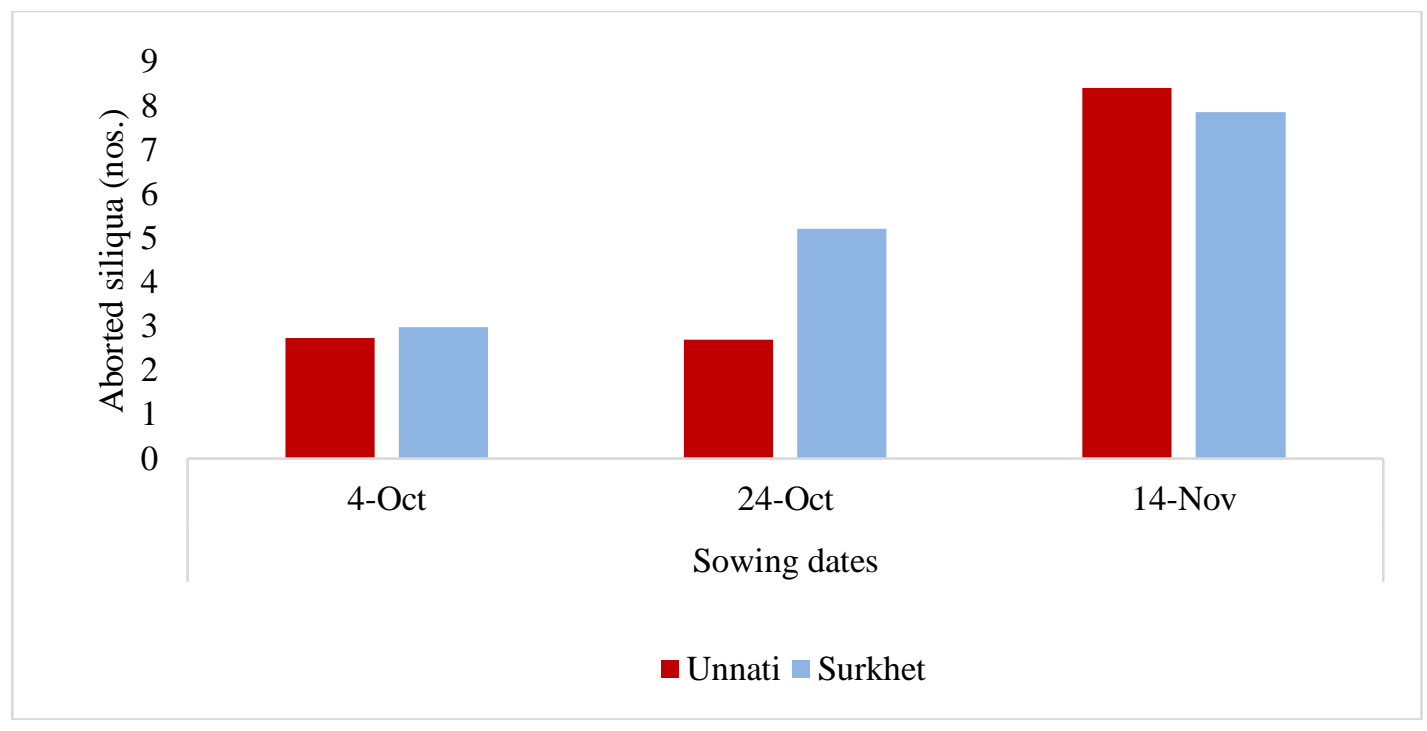

Figure 6. Relation between varieties and date of sowing on aborted seeds per siliqua

\section{Siliqua abortion percentage}

Difference among varieties and their interaction with sowing dates were non- significant but difference in date of sowing had found significant with siliqua abortion \%. Among dates of sowing, highest siliqua abortion \% was found on 14 Nov (13.246\% sown crop followed by 24 Oct $(5.206 \%)$ and the lowest on the date 4 Oct $(2.183 \%)$.

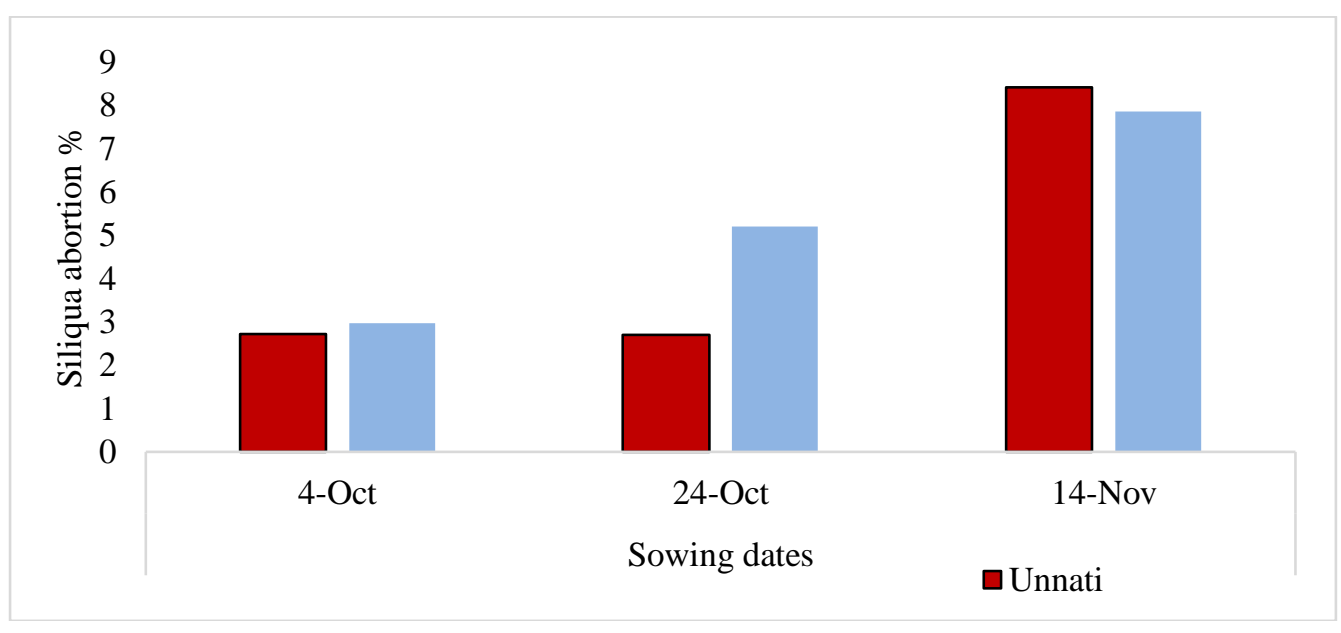

Figure 7. Siliqua abortion \% among different treatments. 
Journal of Agriculture and Natural Resources (2021) 4(1): 176-190

ISSN: 2661-6270 (Print), ISSN: 2661-6289 (Online)

DOI: https://doi.org/10.3126/janr.v4i1.33253

Table 2:Effect of variety and sowing dates on biological yield, seed yield, biomass yield, Harvest index and test weight of rapeseed varieties during winter season, 2018/19.

Yield attributes:

\begin{tabular}{|c|c|c|c|c|c|}
\hline Treatments & $\begin{array}{l}\text { Biological } \\
\text { yield (q/ha) }\end{array}$ & Seed yield (q/ha) & $\begin{array}{l}\text { Biomass yield } \\
(\mathrm{q} / \mathrm{ha})\end{array}$ & $\begin{array}{l}\text { Harvest index } \\
(\%)\end{array}$ & $\begin{array}{l}\text { Test weight } \\
\text { (gm) }\end{array}$ \\
\hline \multicolumn{6}{|l|}{ Variety: } \\
\hline Unnati & 26.276 & 8.54 & 17.73 & $30.37^{\mathrm{a}}$ & 2.91 \\
\hline Surkhet local & 27.05 & 8.59 & 18.45 & $26.77^{\mathrm{b}}$ & 2.70 \\
\hline F-test & NS & NS & NS & $* *$ & NS \\
\hline \multicolumn{6}{|l|}{ Date of sowing: } \\
\hline Oct 4 & $41.957^{\mathrm{a}}$ & $15.939^{\mathrm{a}}$ & $26.017^{\mathrm{a}}$ & $37.978^{a}$ & $3.125^{\mathrm{a}}$ \\
\hline Oct 24 & $22.374^{\mathrm{b}}$ & $7.474^{\mathrm{b}}$ & $14.899^{\mathrm{b}}$ & $33.573^{b}$ & $3.162^{\mathrm{a}}$ \\
\hline Nov 14 & $15.664^{\mathrm{c}}$ & $2.295^{\mathrm{c}}$ & $13.369^{\mathrm{b}}$ & $14.17^{\mathrm{c}}$ & $2.15^{\mathrm{b}}$ \\
\hline F-test & $* *$ & $* *$ & $* *$ & $* *$ & $* *$ \\
\hline Interaction & NS & NS & NS & $* *$ & NS \\
\hline $\mathrm{CV}(\%)$ & 22.78 & 25.13 & 22.57 & 6.64 & 16.33 \\
\hline Grand mean & 26.66 & 8.56 & 18.09 & 28.57 & 2.81 \\
\hline LSD & 6.303 & 2.35 & 4.085 & 2.820 & 0.444 \\
\hline
\end{tabular}

Note: $N S=$ Non-significant, $*=$ Significant and $* *=$ Highly significant, $C V=$ Coefficient of Variation, LSD = Least Significant Difference.

\section{Seed yield}

Seed yield was found to be highly significant to dates of sowing whereas non-significant to varieties and interactions between them. The higher seed yield obtained on Oct 4 (15.93 q/ha) followed by seed yield on Oct 24 (7.47 q/ha) and the lowest yield on Nov 14(2.29 q/ha). Auld et al., (1991);Mendham and Scott, (1975); Scarisbrick et al., (1982);Taylor and Smith, (1992) and Thurling, (1974) also found a reduced rapeseed seed yield in delayed date of sowing. The higher seed yield obtained in early sowing is due to longer reproductive phase whereas shorter growth and shorter span of reproductive phase are the reason behind the reduced seed yield.

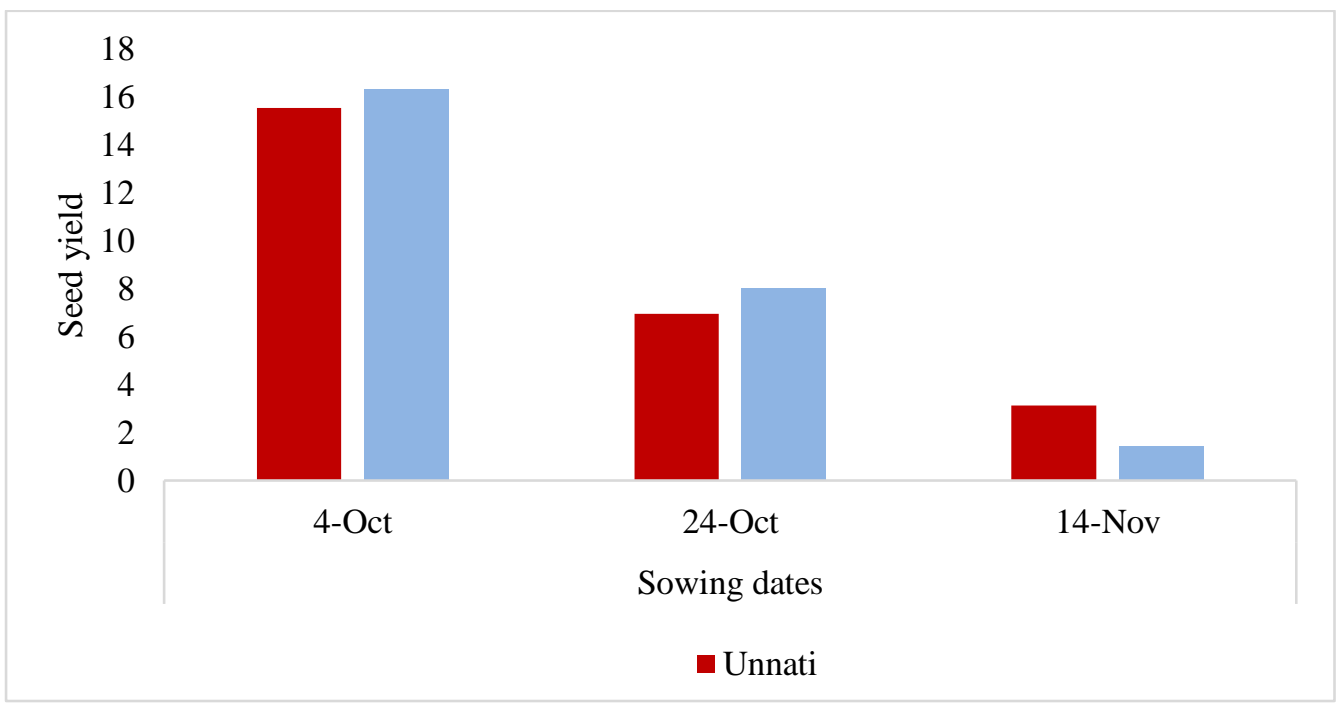

Figure 8. Effect of different treatments on seed yield (q/ha)

\section{Biological yield and biomass yield}

Biological yield was found significant with dates of sowing while it was found to be nonsignificant with both varieties and their interaction. The highest biological yield was found in 
Oct 4 (41.95 q/ha) followed by Oct 24 (22.37 q/ha) and the lowest was found in Nov 14(15.66 $\mathrm{q} / \mathrm{ha}$ ). As we know biological yield is combination of both biomass and seed yield. As assimilate transition efficiency to economical sinks (grains) is decreased, seed yield also decreased. The reduced vegetative growth, seed and stalk yield in later dates of sowing cause reduction of biomass yield on later sowing dates. Being reduction of biomass yield and seed yield, biological yield also reduced. The results were consistent with studiesof Rao \& Mendham, (1991); Taylor \& Smith, (1992) andWhitfield, (1992). The late planting of canola adversely affect the yield and yield components due to its adverse effect on growth, because the different growth stages canola acquired enough time for their development(Muhammad et al., 2002).

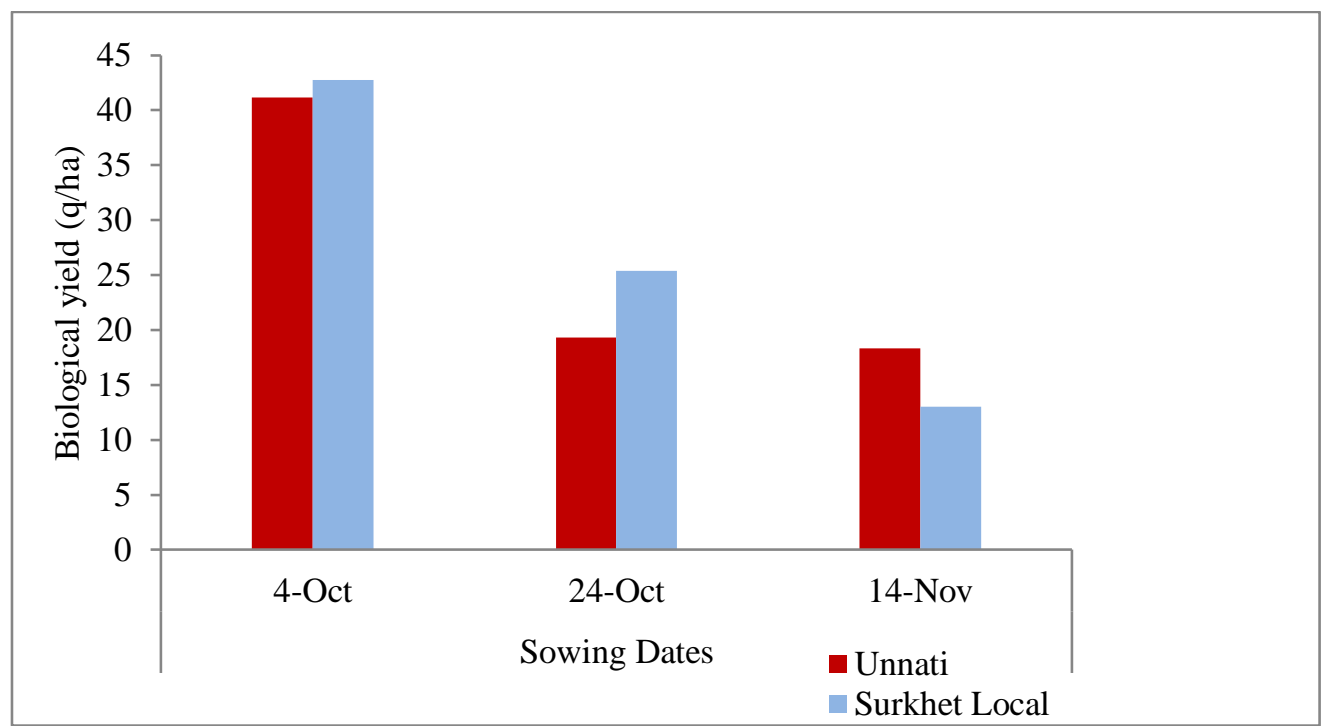

Figure 9. Effect of varieties and date of sowing on biological yield

Biomass yield was found to be non significant with varieties and significant with dates of sowing and their interaction. The highest biomass yield was found on Oct 4 sown crop (26.017 q/ha) followed by Oct 24 (14.899 q/ha) sown crop which is at par with Nov 14 sown crop $(13.369 \mathrm{q} / \mathrm{ha})$. This result might be due to the reduced vegetative growth, seed and stalk yield in later dates of sowing.

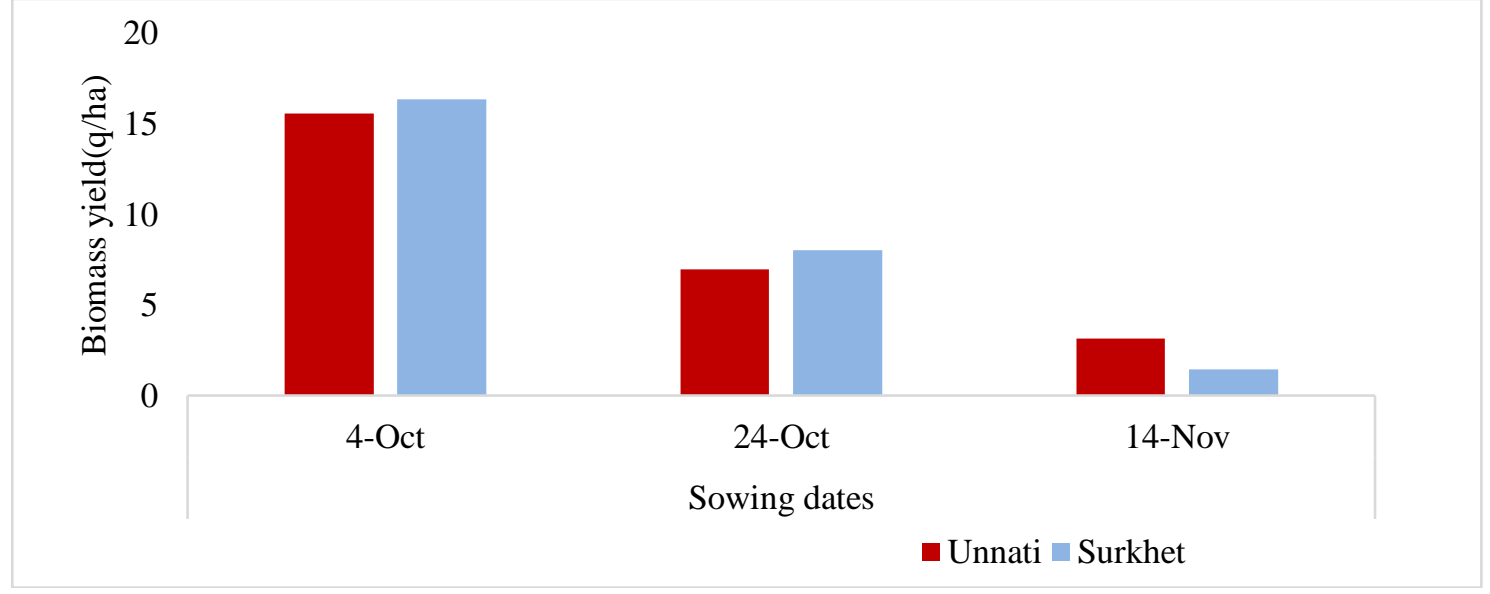

Figure 10. Effect of varieties and date of sowing on biomass yield 


\section{Harvest index}

Harvest index differed significantly due to varieties and date of sowing. Also, the significant difference was shown by their interaction. In case of variety, higher harvest index was recorded in variety Unnati while it was obtained significantly more in Oct 4 in case of date (Table 2.).Harvest index interaction was significant and higher in variety Surkhet sown on Oct 4 (38.13\%). Lowest harvest index was recorded on variety Surkhet sown on delayed date i.e. Nov $14(11.21 \%)$.The results were similar with the findings ofRao \& Mendham, (1991) and Whitfield, (1992). Scarisbrick et al., (1982)reported that HI reduction due to delayed sowing was the major cause which leads into decreased seed yield. This may be due to the higher seed yield and higher test weight of Unnati variety. Scarisbrick et al., 1982 also reported that harvest index reduction due to delayed sowing was the major cause which leads into decreased seed yield.

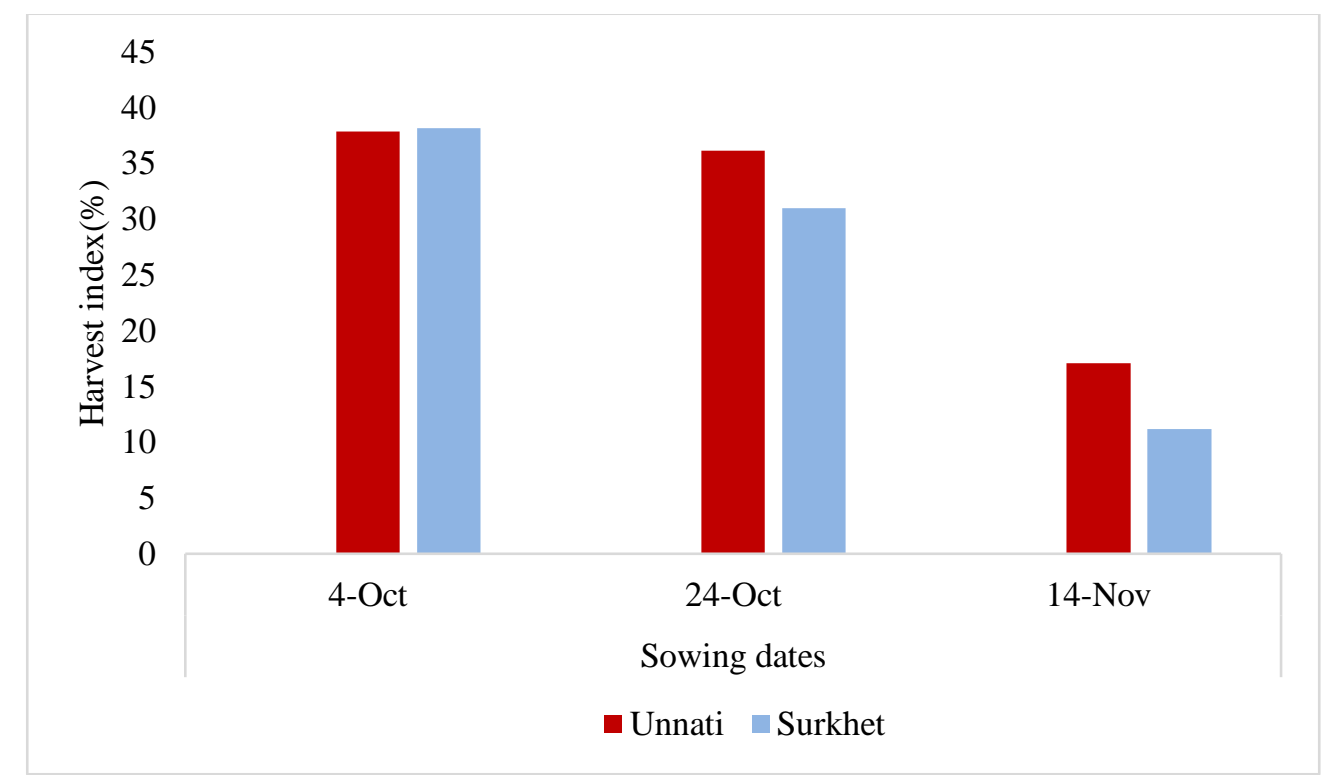

Figure 11. Effect of date of sowing on Harvest index

\section{Test weight}

Highest test weight was recorded in October 24 (3.16 gm) sown crop which is at par with October 4(3.125 gm) and lowest test weight was found on 14 Nov (2.15 gm) shown crop. It revealed that dates of sowing showed highly significant effect on test weight while varieties and their interaction with sowing dates didn't show any significant effect. A decreasing trend was recorded from the earliest date of sowing to the last date. These findings are in agreement with Brar et al., (1998); Bali et al., (1992) in gobi sarson andChauhan et al., (2007) in rayo. 


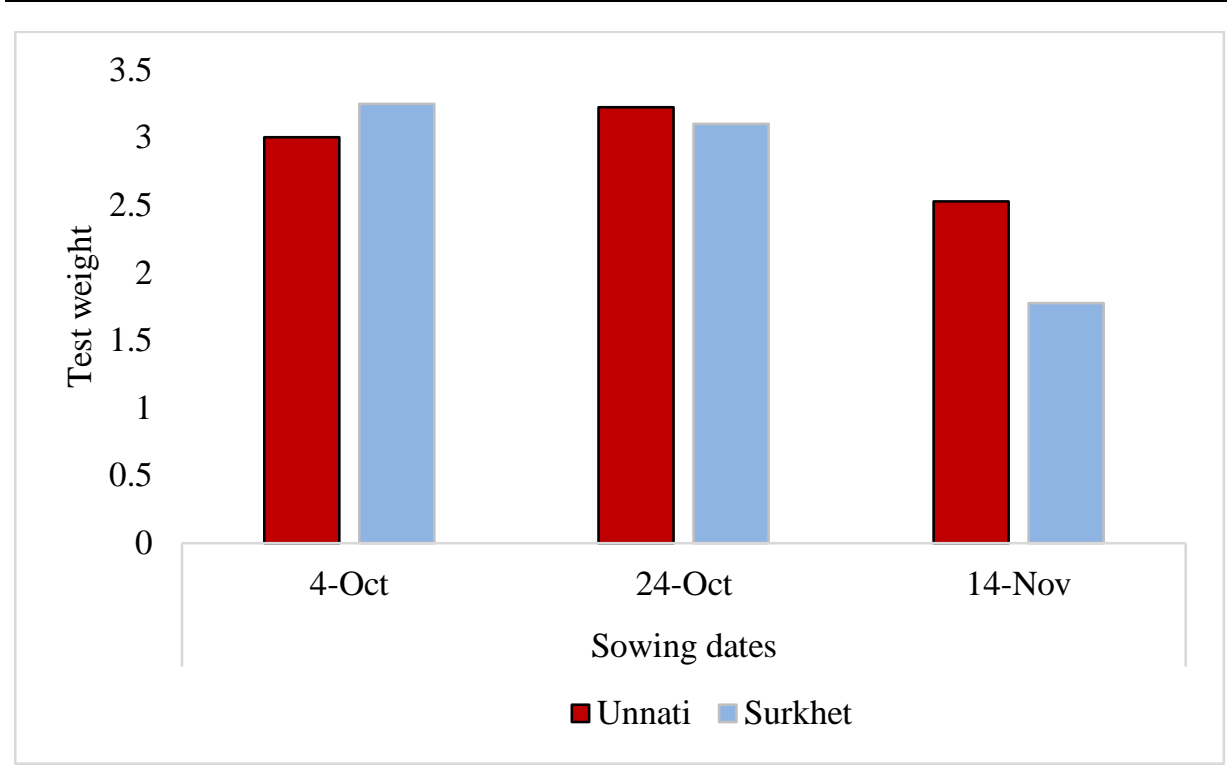

Figure 12. Effect of date of sowing on test weight (gm)

\section{CONCLUSION}

The present study concluded that there is presence of significant difference among the different sowing dates in Dang condition. We found that both the varieties, i.e. Unnati and Surkhet Local sown in Oct 4 had higher yield rather than sown in Oct 24 and Nov 19. Since sowing date and variety selection is one of the most important factor in increasing productivity, appropriate date would help in escaping yield reducing factors such as frost, pest attack and insufficient reproductive period. Even though, this study did not show significant differences among two varieties, appropriate variety would perform better in recommended domain. Since, climate change has been a major issue for fluctuation of the global temperature in recent times, further researches on appropriate date of sowing would help in maximizing and maintaining the yield.

\section{ACKNOWLEDGEMENTS}

We feel delighted to express a deep sense of gratitude to those personals that supported us directly and indirectly during the entire period of our study, research and in the critical period of manuscript preparation. We feel a great pleasure to express our profound sense of gratitude to the respected Advisor Mr. Yogendra Katuwal, Assistant Professor, Department of Agronomy, Institute of Agriculture and Animal Science, Campus of Live Sciences for his valuable suggestions, constructive comments and constant encouragement throughout the planning and execution of our research. We would like to express our profound gratitude to Advisory Committee Member Mr. Siddha Lal Bohara, Asst. Prof. Department of Agronomy, Campus of Live Sciences for his suggestions and constant encouragements. We owe our sincere and deep sense of gratitude to all the members of Campus of Live Sciences for their excellent institutional support for the successful completion of our study.Our deep sense of regards goes to Campus Chief Prof. Dr. Shadeo Sah for his encouragements, support and insightful comments. Special thanks to Mr. Ram Chaudhary, lab boy, Department of Agronomy, IAAS Campus of Live Sciences for his valuable support and management during the conduction of our field research. Special thanks are owed to our colleagues including all our friends and juniors for their support to conduct field research activities. 
Journal of Agriculture and Natural Resources (2021) 4(1): 176-190

ISSN: 2661-6270 (Print), ISSN: 2661-6289 (Online)

DOI: https://doi.org/10.3126/janr.v4i1.33253

\section{Authors' Contributions}

G. Ranabhat and P. Tiwari analyzed, conducted, and prepare the manuscript of the experiment. A. Dhakal and P. Oli collected all the information from fields and extracted information from literatures and prepared figures and table. A. Chapagain revised the final paper, S. Neupane helped in the experiment and G. Ranabhat edited whole manuscripts, language checking, and verified the analysis and data presented in the manuscript.All author approved the final version of this manuscript.

\section{Conflict of interest}

The authors declare no conflicts of interest regarding the publication of this manuscript.

\section{REFERENCES}

Alam, M. M., Begum, F., \& Roy, P. (2014). Yield and yield attributes of rapeseed - mustard (Brassica) genotypes grown under late sown condition. Bangladesh Journal of Agricultural Research, 39(2), 311-336. https://doi.org/10.3329/bjar.v39i2.20434

Andersson, B., \& Benglsson. (1989). The influence of row spacing, seed rate and sowing time on over wintering and yield in winter oilseed rape (Brassica napus). Swedish J. Agric. Res., 19, 129-134.

Angadi, S. V., Cutforth, H. W., McConkey, B. G., \& Gan, Y. (2003). Yield Adjustment by Canola Grown at Different Plant Populations under Semiarid Conditions. Crop Science, 43(4), 1358-1366. https://doi.org/10.2135/cropsci2003.1358

Auld, D. L., Mahler, K. A., Thrill, D. C., Erickson, D. A., Raymer, P. L., \& Sernyk, J. L. (1991). Registration of Two Rapeseed Germplasm Populations. Crop Science, 31(2), 493-494. https://doi.org/10.2135/cropsci1991.0011183X003100020078x

Baghdadi, H., Taspinar, S., Yousefi, M., \& Hosseinpour, A. (2012). Influence of different sowing dates on grain yield of canola (Brassica napus L.) cultivars in Qazvin area. Intl. $J$ Agric: Res \& Rev, 2, 1092-1096.

Bali, A. S., Singh, T., Shah, M. H., Singh, K. N., \& Nehvi, F. A. (1992). Response of Indian mustard (Brassica juncea) to sowing date and fertilizer application. Indian J. Agric. Sci., 62, 690-691.

Basnet, K. (2005). Effect of Different Combinations of Nutrient Sources and Weeding Practice on the Physiological Characters of Rapeseed in Humid Subtropical Condition of Chitwan. Journal of the Institute of Agriculture and Animal Science, 26, 51-55. https://doi.org/10.3126/jiaas.v26i0.611

Bhandari, R. (2015). Plant Oils in Nepal: A Potential Alternative Energy to Fossil Fuel. EC Agriculture, 1(2), 86-97.

Bhatta, K., Chaulagain, L., Kafle, K., \& Shrestha, J. (2019). Bio-Efficacy of Plant Extracts against Mustard Aphid (Lipaphis erysimi Kalt.) on Rapeseed (Brassica campestris Linn.) under Field and Laboratory Conditions.Syrian Journal of Agricultural Research, 6(4), 557-566

B.K., S.B, Karki, T.B., Shrestha, J., \& Adhikari, P. (2015). Productivity of maize genotypes under different planting dates. Our Nature, 13(1), 45-49. DOI: http://dx.doi.org/10.3126/ on.v13i1.14208

Brar, S., Z., Bal, S., D., \& John, A. S. (1998). Influence of sowing dates, nitrogen and planting geometry on the performance of Gobhi Sarson (Brassica napus spp. olefera var. annua). Indian J. Agron, 43(1), 133-137.

Chaudhary, N. K., Sharma, R. C., Mishra, N. K., \& Dahal, K. R. (1993). Weed and fertilizer 
Journal of Agriculture and Natural Resources (2021) 4(1): 176-190

ISSN: 2661-6270 (Print), ISSN: 2661-6289 (Online)

DOI: https://doi.org/10.3126/janr.v4i1.33253

management in rapeseed and mustard. NORP Annual report.

Chauhan, J. S., Tyagi, M. K., Kumar, A., Nashaat, N. I., Singh, M., Singh, N. B., Jakhar, M. L., \& Welham, S. J. (2007). Drought effects on yield and its components in Indian mustard (Brassica juncea L.). Plant Breeding, 126(4), 399-402. https://doi.org/10.1111/j.14390523.2007.01394.x

FAOSTAT. (2019). FAOSTAT. http://faostat3.fao.org/faostat-gateway/go/to/browse/Q/QC/E

Fathi, G., Siadat, S. A., \& Hemaiaty, S. S. (2003). Effect of sowing date on yield and yield components of three oilseed rape varieties. Acta Agronomica Hungarica, 51(3), 249-255. https://doi.org/10.1556/AAgr.51.2003.3.2

Fink, N., Conley, S., \& Christmas, E. (2006). An Evaluation of the effectsof planting date and seeding rate on the yield of winter Canola grown at three different geographic areas. The ASA-CSSA-SSSA, International Annual Meetings.

Ghimire, T. B., Chaudhary, R. N., \& Ray, S. P. (2000). Quantification of yield limiting constraints in toria production.NORP Annual report.

Gomez, K.A., \& Gomez, A.A. (1984). Statistical procedures for agricultural research. 2nd edn. International Rice Research Institute, College, Laguna, pp. 680.

Hasanuzzaman, M., Karim, M., \& Ullah, M. (2008). Growth dynamics of rapeseed (Brassica campestris L.) cv. SAU Sarisha-1 as influenced by irrigation levels and row spacings. Australian Journal of Basic and .Applied Science, 2, 794-799.

Hocking, P. J., \& Stapper, M. (2001). Effects of sowing time and nitrogen fertiliser on canola and wheat, and nitrogen fertiliser on Indian mustard. I. Dry matter production, grain yield, and yield components. Australian Journal of Agricultural Research, 52(6), 623. https://doi.org/10.1071/AR00113

Mendham, N. J., \& Scott, R. K. (1975). The limiting effect of plant size at inflorescence initiation on subsequent growth and yield of oilseed rape ( Brassica napus ). The Journal of Agricultural Science, 84(3), 487-502. https://doi.org/10.1017/S0021859600052709

MoAC. (2012). Statistical information on nepalese agriculture.

MOADSTAT. (2016). Statistical agriculture book. http//moad.gov.np/public/uploads/1142453195statistic agriculture book_2016.pdf

Muhammad, Y., Amir, A., Jahangir, M., \& Naseeb, T. (2002). Effect of Different Sowing Dates on the Growth and Yield of Canola (Sarson) Varieties. Asian Journal of Plant Sciences, 1(6), 634-635. https://doi.org/10.3923/ajps.2002.634.635

Prasai, H. K., \& Yadhav, H. N. (1999). Performance evaluation of mustard at Banigama, Morang.Annual Report.Regional Agriculture Region Station, Tarahara, Nepal.

Rao, M. S. S., \& Mendham, N. J. (1991). Soil-plant-water relations of oilseed rape ( Brassica napus and B. campestris ). The Journal of Agricultural Science, 117(2), 197-205. https://doi.org/10.1017/S002185960006528X

Robertson, M. J., Holland, J. F., \& Bambach, R. (2004). Response of canola and Indian mustard to sowing date in the grain belt of north-eastern Australia. Australian Journal of Experimental Agriculture, 44(1), 43. https://doi.org/10.1071/EA02214

Scarisbrick, D. H., Daniels, H., \& Rawi., A. B. N. (1982). Effect of varying seed rate on the yield and yield components of oil-seed rape (Brassica napus). J. Agric. Sci.Camb., 99(3), 561-568.

Scarisbrick, D. H., \& Daniels, R. W. (1984). Oilseed rape. Outlook on Agriculture, 13(3), 118124. https://doi.org/10.1177/003072708401300301

Sharma, K. C. (1994). Current Experiences and Practices in Pesticide Use in the Bagmati Zone. In Discussion Paper. http://lib.icimod.org/record/23842 
Shrestha, J., Kandel, M., \& Chaudhary, A. (2018). Effects of planting time on growth, development and productivity of maize (Zea mays L.). Journal of Agriculture and Natural Resources, 1(1), 43-50. https://doi.org/10.3126/janr.v1i1.22221

Shrestha, J. (2019). P-value: a true test of significance in agricultural research. Retried https://www.linkedin.com/pulse/p-value-test-significance-agricultural-research-jibanshrestha. DOI: http://doi.org/10.5281/zenodo.4030711

Sudeep, S., Pannu, R. K., \& Tenjinder, S. (1996). Effect of sowing time on the growth and yield of Brassica genotypes. Ann. Biol. (Ludhiana), 12, 287-293.

Taylor, A., \& Smith, C. (1992). Effect of sowing date and seeding rate on yield and yield components of irrigated canola (Brassica napus L.) grown on a red-brown earth in southeastern Australia. Australian Journal of Agricultural Research, 43(7), 1629. https://doi.org/10.1071/AR9921629

Thakur, K. S., \& Singh, C. M. (1998). Performance of Brassica species under different dates of sowing in mid-hills of Himachal Pradesh. Indian Journal of Agronomy,43(3), 464-468.

Thurling, N. (1974). Morphophysiological determinants of yield in rapeseed. Aust. J. Agric. Res., 25, 11-21.

Uzun, B., Zengin, U., Furat, S., \& Akdesir, O. (2009). Sowing date effects on growth, flowering, seed yield and oil content of canola cultivars. Asian Journal of Chemistry, 21, 1957-1965.

Whitfield, D. M. (1992). Effects of temperature and ageing on CO2 exchange of pods of oilseed rape (Brassica napus). Field Crops Research, 28(4), 271-280. https://doi.org/10.1016/0378-4290(92)90013-Y. 